\title{
The Specificity of Innovative Activity in a Vertically Integrated Oil Companies
}

\author{
Elena A. Shishkina ${ }^{1}$, Sergey V. Kiselev ${ }^{2}$, Guzyal M. Kharisova ${ }^{3}$, Natalia M. Chikisheva ${ }^{4}$, Irina Y. Litvin ${ }^{5}$, Larisa \\ E. Fatikhova ${ }^{1} \&$ Boris B. Khrustalev ${ }^{6}$ \\ ${ }^{1}$ Kazan (Volga region) Federal University, Kazan, Russia \\ ${ }^{2}$ Kazan National Research Technological University, Kazan, Russia \\ ${ }^{3}$ Kazan State University of Architecture and Engineering, Kazan, Russia \\ ${ }^{4}$ Tyumen state University of Architecture and Construction, Tyumen, Russia \\ ${ }^{5}$ Moscow State University of Mechanical Engineering, Moscow, Russia \\ ${ }^{6}$ Penza State University of Architecture and Construction, Penza, Russia \\ Correspondence: Elena A. Shishkina, Kazan (Volga region) Federal University, 420008, Kremlyovskaya Street, \\ 18, Kazan, Russia.E-mail: rida@mail.ru
}

\author{
Received: April 16, 2015 Accepted: April 26, 2015 Online Published: May 28, 2015 \\ doi:10.5539/jsd.v8n3p211 URL: http://dx.doi.org/10.5539/jsd.v8n3p211
}

\begin{abstract}
The importance of the petroleum sector in the domestic economy today cannot be overestimated in connection with its role as a revenue generating industry, which is especially relevant the study of specific features of innovative directions in development of the industry and improve its competitiveness and economic efficiency. The article deals with the specifics of innovative activity in a vertically integrated oil companies, consisting of its own research base, the active use of the mechanisms with foreign technology borrowing, acquisition of assets from related industries and organization of joint projects and the establishment of joint innovative companies developing innovative technologies. All this has allowed the authors to substantiate the benefits of the organizational form of the vertically integrated oil companies, including the concentration of all types of resources, the formation of personnel motivation system, reduction of transaction costs, more efficient information exchange, minimize innovative risks and several others. Management system within the vertically integrated oil companies helps to ensure an adequate level of structure management, integrating technological and management options of innovative activity. This article is intended for researchers, teachers and undergraduates studying the specificity of innovative activity in a vertically integrated oil companies, and managers of oil companies, who is developing the strategy of innovative development.
\end{abstract}

Keywords: vertically integrated oil companies, innovative activity, technological innovation, foreign direct investment, foreign technology borrowing, innovation risks

\section{Introduction}

\subsection{The Urgency of the Problem}

The modern development of the domestic economy may not be considered as sustainable one due to the fact that its parameters are provided mainly by the favorable situation on the world commodity markets. GDP (gross domestic product) growth is ensured by the extensive growth of the commodity sector, accompanied by rising expenses of different types of resources (Kontorovich et al., 2008). On the other hand, the reduction and depletion of resource stocks stimulates the search of resource-efficient models in commodity sector development and control of its innovative development in order to overcome the increasing cost trends and improve the efficiency of existing resource base (Zaichenko, 2010). The share of hard-to-recover oil in Russia today accounts for about $60 \%$ of the remaining reserves, and specific operating expenses at these fields significantly (3-5 times) exceed the industry's average (Alekperov, 2009). The use of traditional technologies for oil extraction and exploitation of hard-to-recover oil reserves is highly inefficient and does not provide a return of such investment projects (Garayev, 2012).

Therefore the search for innovative and high-effective technologies for hard-to-recover oil reserves development, 
reducing production expenses and increasing the volume of recoverable oil, are the most urgent problems in the operation of oil companies. Innovative activity aimed at the development and implementation of technological innovations, as the analysis shows is most effectively realized in the oil sector in a managerial form of vertically integrated companies, which is proved by a number of deep theoretical and practical research taking place in modern conditions by foreign and domestic scientists (Kovaleva, 2000).

\section{Methodological Framework}

\subsection{Objectives of the Study}

The objective of the study is the identification and justification of the specific characteristics of innovative activity in vertically integrated oil companies, the study of the organizational and managerial benefits of the oil sector in the development and implementation of investment and innovation projects, the structure of oil production market, as well as organizational and managerial differences between domestic and foreign models of vertical integration in the oil industry.

\section{Results}

\subsection{Justified Organizational and Managerial Advantages of Vertical Integration in the Oil Industry Are Justified}

According to most researchers, vertical integration is the unification of the financial and economic basis of various technologically interrelated industries. In the petroleum industry it includes enterprises related to sequence stages of the technological process: exploration and oil production - transportation - refining petrochemicals - marketing of petroleum products. This organizational form enables to adequately respond to the processes of market relations creation, organically fit into the production process research division, conducting $\mathrm{R}$ \& D (Research and Development,) to expand the boundaries of innovation management at all levels of company management which can significantly improve the effectiveness of managerial decisions in the conditions of dynamic market conditions (Alekperov, 2009). Experience in the development of vertical integration models in the foreign oil companies, whose number now exceeds 100, with the apparent objectivity proves their effectiveness. It should be noted that the formation and development of the oil business abroad initially followed the path of vertical integration. So, the largest foreign oil companies - "Standard Oil", "Gulf", "Texaco", "Shell", "Chevron", "Mobil", "Amoco", "British petroleum" - now control all areas of the oil business, including its innovative technological development.

In the domestic economy the emergence of the prerequisites for vertically integrated oil companies (VIOCs) creation began to form only after a number of basic legal acts' adoption. This concerns, above all, the presidential Decree of 1 July 1992 "On the status of the production and scientific-production associations of the fuel and energy complex" (decree of the President of Russian Federation of 1.06.92), presidential Decree dated August 14, 1992 "On peculiarities of transformation of state enterprises, associations and organizations of fuel and energy complex into joint-stock companies" (decree of the President of the Russian Federation of 14.08.92) and presidential Decree No. 1403 dated 17 November 1992 "On peculiarities of privatization and transformation of state enterprises, production and scientific-production associations of oil, the refining industry and oil product supply into joint stock companies," (decree of the President of the Russian Federation of 17.11.92.). These documents formed the institutional basis for oil companies privatization, ownership rights transfer on state geological, mining, processing and marketing enterprises to some biggest oil companies, and laid the foundations of vertical integration in the oil industry. In accordance with the above mentioned decrees $51 \%$ of the ordinary shares was transferred to the Federal property and remained fixed by the state for 3 years. Institutional changes in the industry naturally led to the prevention of the collapse in the industry and the gradual restoration of oil production till the level, which was fixed during Soviet times (see Fig. 1.). 


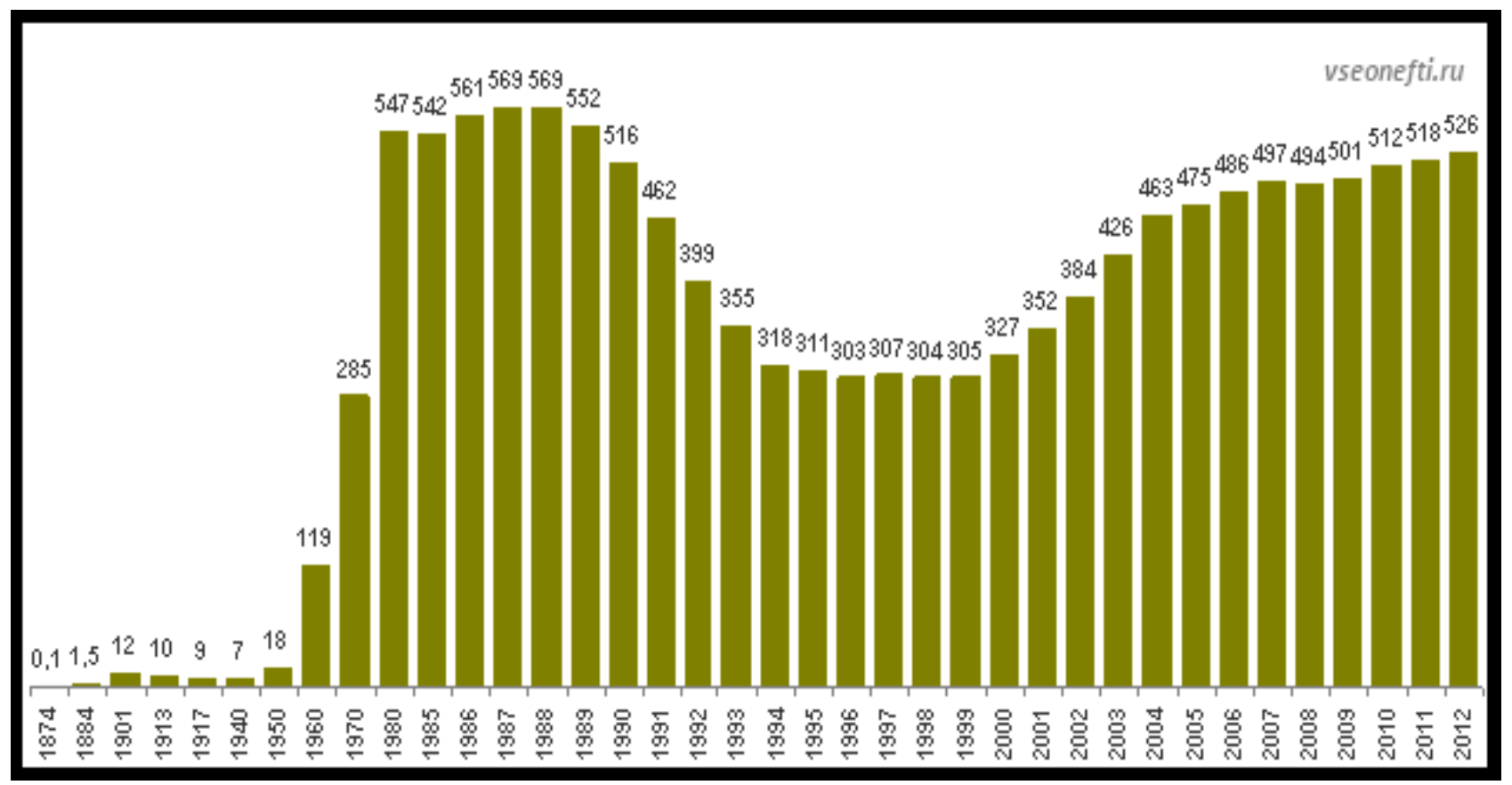

Figure 1. The dynamics of oil production in Russia, million tons

According to official statistics data, the volume of oil production in Russia in 2012 amounted to 526,2 million tons, and experts predicted in 2014 Russia would reach the level of 90-ies with the last century in oil production volumes. Currently oil and gas sector provides $70 \%$ of the total consumption of primary energy and almost $80 \%$ of their production. The share of the oil and gas industry accounts for over $40 \%$ of tax revenues in the Federal budget and more than $20 \%$ in the consolidated budget of the country.

Most authors see in the model VIOCs advantages which are associated with the production processes, transportation, refining and marketing of oil production products (Kuznetsova, 2011). This organizational-managerial form has great potential for intensive innovative development. The presence of powerful financial and intellectual basis allows VIOCs to develop integration processes in the sphere of new technologies' innovative development which can be occurred in the following forms:

- attracting of direct foreign and domestic investment in order to develop innovative technologies for the extraction, transportation, refining, marketing techniques, etc.;

- using of foreign innovative technologies' borrowings in the domestic market of oil production with their subsequent adaptation to the institutional environment of the domestic economic environment;

- acquisition (merger) of tangible and financial assets of available companies in various sectors of economic activity in order to create the material and technical, intellectual basis for innovative development of technology;

- organizing of joint projects and the establishment of joint innovative companies developing innovative technologies.

\subsection{Oligopolistic Structure of Oil Production Market Is Systematized}

The emerging transformation in the industry has led to the formation and development of specific competitive relationship, which actually resulted to the oligopoly market model emergency, which included the following groups of companies (Alekperov, 2009):

- the first group was formed by oil and gas Association, incorporated as a single technological complex, $38 \%$ the shares of which were fixed for 3 years in Federal ownership and transferred to the management of the state enterprise "Rosneft";

- the second group was formed by joint stock companies "LUKOIL", "YUKOS" and "Surgutneftegaz", which were formed on the basis of five Tyumen oil associations, five large complexes for oil refining and 18 specialized organizations to ensure the oil regions of Central and North-Western regions, the Volga region, the Urals. The authorized capital of the newly established oil companies were formed from $38 \%$ of the shares of subsidiaries. Controlling companies (49\%) of 3 years was fixed in Federal ownership. The composition of the 
governing bodies of vertically integrated oil companies were approved by the Government of the Russian Federation;

- the third group was formed by a newly created companies JSC "Transneft" and JSC "Transnefteproduct" which were associated with the oil transportation and oil products, $49 \%$ of which were fixed in Federal ownership for three years.

The past two decades has led to the fact that today specialists in this field classify four groups of VIOCs, differing by organizational and managerial characteristics and which are the largest companies in oil production (see tab. 1.):

- Vertically integrated oil companies, which are completely controlled by the state, and which includes JSC "Gazprom Neft" JSC "Gazprom" and JSC "OC "Rosneft";

- VIOCs under the control of the Federation entities, including JSC "Tatneft" and JSC "Bashneft";

- VIOCs under the control of management, including JSC "LUKOIL", JSC "OC "RussNeft" and JSC "Surgutneftegas";

- VIOCs which belong to financial-industrial groups, which include JSC "TNK-BP Holding", JSC "NGK "Slavneft" and JSC "Bashneft".

The analysis shows that the state strategy in creating of the institutional basis for the formation of vertically integrated oil companies meant to maintain control over the oil production industry, as natural monopolies of the state and a vital source of revenues of the Federal and regional budgets.

Table 1. Ten largest Russian vertically integrated oil companies in oil production in 2011

\begin{tabular}{ll}
\hline The name of the company & Production, million tons \\
\hline "Rosneft" & 114,6 \\
"LUKOIL" & 85,3 \\
TNK-BP holding & 72,6 \\
"Surgutneftegas" & 60,7 \\
"Gazprom Neft" & 30,3 \\
"Tatneft" & 26,2 \\
"Slavneft" & 18,08 \\
"Bashneft" & 15,1 \\
"Gazprom" & 14,3 \\
"RussNeft" & 13,6 \\
\hline
\end{tabular}

According to the experts (Bushuev, 2008) if a major Western companies during the "soft" evolutionary vertical integration in the 60-ies of the last century overcame national borders, the Russian vertically integrated oil companies were created within a short period of time in accordance with the "hard" decisions of the President and Government. The historic inability of the evolutionary path in development of Russian vertically integrated oil companies, the lack of competitive relations experience, a huge reservoir of unresolved issues inherited from the Central planning economy, their own mistakes during the privatization and consolidation of assets proved to be blocking factors in the way of vertical integration of large oil business in Russia and its integration into the world energy system.

\subsection{Organizational and Managerial Differences of Vertical Integration National Model in the Oil Industry from Foreign Model Are Disclosed}

There are two types of vertically integrated companies in modern conditions, the first of which includes a scientific research units, innovation centers, small innovative companies in its structure as instruments of innovation development. Another type of VIOCs is focused on innovative growth by foreign mechanisms borrowing for innovative domestic technologies practice in the oil sector, to adapt them to Russian conditions and creation on this basis of starting opportunities for innovative growth. However, this classification is very conditional, as most modern vertically integrated oil companies try to use all available tools to maintain a 
sustainable competitive position on the oil production world market.

According to some specialists (Berezina \& Cherepovicyn, 2014) for the Russian oil industry, possessing all stages of the oil cycle, reform through the creation of vertically integrated oil companies is quite natural thing, but, there are some characteristic differences between classical vertically integrated companies and their Russian version. Thus, the Western vertically integrated oil companies developed organically as the development of the market and the degree of institutionalization, via mergers and acquisitions of some other companies, diversification and specialization of their activity. Russian vertically integrated oil companies were artificially created through administrative decisions, government support, sometimes against the trends of market development mechanisms, their competition, or rather the competition method was imposed by the state forcibly, which could not help of affecting the deformation of market relations in the industry. The new organizational and managerial format of VIOCs joined the enterprises, which had been functioning for decades under various ministries and departments in the centrally planned economy conditions. In this condition the set of both merging companies was characterized, as a rule, as administrative by nature, had a significant trend of unilateral interests of the state or its agencies, which didn't had sufficient technological and managerial rationale always. Therefore, the problem of their interaction and transformation in the single economic, managerial, technological body turned into a painful process, which has not finished yet so far (Guseinov, 2011). The shape of organizational and managerial interaction of the enterprises included in the majority of Russian vertically integrated oil companies is known worldwide as "soft holding", which means the operational independence of the production, marketing, and logistics activities among themselves, the lack of a unified strategic development model. Therefore, the strategic goal of this kind VIOCs is blurred, has no distinct purpose and methods of its achievement, and the members of his subsidiaries have the opportunity or be out of a single strategic lines in the development of vertically integrated oil companies. The cause of this situation experts see again in administrative "hard" creation of domestic VIOCs, when industrial problems in various industries tried to solve them via merge into one organizational and management structure with the purpose of most effective solutions making. However, in real practice, these problems in some cases have not been resolved, and in some cases turned into chronic conditions (Zaichenko, 2010).

3.4 The Specificity of Vertical Integration Effects on the Process of Oil Companies Innovative Development Are Justified

The above mentioned trends in vertically integrated companies' national model creating significantly influenced the level and depth of their innovation development, when the industry significantly reduced the level of research intensity in comparison with the Soviet period. This condition or trend presence is due to the roots, when the presence in the VIOCs of relatively large concentration of all types resources, primarily financial, deprives them of motivation to the development of industrial science, as it is much cheaper in all respects to buy a new, relatively innovative (imitative) technology abroad than to spend huge financial, staffing and managerial resources to develop their own innovations in the framework of their own research infrastructure.

As research specialists confirmed, more than $70 \%$ of funds allocated for innovation and improvement in the oil industry, is used for the purchase of new technology and new equipment. The level of innovative activity among Russian vertically integrated oil company remains at a very low level, giving even low-tech industries. So, in 2010 the level of innovative activity (as the ratio of the vertically integrated oil companies engaged in innovation activities to the total number) of oil -and gas complex enterprises accounted for only 8.7 percent, 5.8 per cent of which was accounted for by technological and $2.6 \%$ for organizational and managerial innovations. In other words, the oil and gas organizations complex has no motivating factors to enhance their own innovative technological developments. Global oil and gas industry is sufficiently developed and mature sector of the economy that, on the one hand, it reduces the possibility of innovations' widespread introduction. Partially this may explain the inherent relatively low R \& D intensity, measured as the ratio of R \& D expenditures to sales. According to analysis data of the EU, USA and Japan industries, R \& D intensity on oil and gas companies in 2012 amounted to 0.3 percent, while automotive corporations - 4,2\%, IT-corporations - 9,5\%, pharmaceutical 15,1\% (Hochberg, 2006).

At the same time, the growth in the share of hard to recover oil, which is faced by all Russian oil companies, forcing intensively to improve all the activities, ranging from drilling till production and work over. Habitual activities, acquire a "new breath" at the expense of innovation and improvements ensuring more rational use of resources, more effective implementation of technological processes.

Theoretical analysis and research practical experience in the field of oil production puts forward a number of provisions to support the mechanism of foreign innovative technologies "borrowing" proposed by V. N. 
Polterovich (2010). The content of this mechanism may not be in "the creation of fundamentally new technologies, but in importing, transferring, modification and distribution of mechanism of adopted technologies which have already proven their effectiveness. This mechanism causes the so-called effect of "spill-over", or blends of technological externalities from one vertically integrated oil company to another, due to the exchange of technical and organizational information.

It is not secret that in the oil sector of the economy the level of research intensity is relatively low, and qualification level of specialists doesn't not always allow create a globally competitive innovative technologies. Experience shows that the vast majority of product and technological innovations in vertically integrated oil companies are imitating by nature and are innovations only for Tatarstan and Russia. As a way out of this situation a number of specialists see in the oil production this borrowing mechanism using as....the introduction of more efficient technologies and practices already established by leaders" (Polterovich,2010). However, experts warn: to borrow is not always the best thing, as foreign advanced technology, as a rule, cannot be adapted to the domestic economic conditions in underdeveloped institutional and information environment. The processes of technological and institutional reform need to move, as shown by the theory of new institutionalism, according to the agreed trajectory. Only under such conditions, the creation of perspective economic, organizational and managerial environment is possible in the framework of vertically integrated companies with innovative receptive technological and institutional infrastructure.

The leading role in the borrowing mechanism under VIOCs belongs to tools of foreign advanced technologies' absorption, which have proven their effectiveness in the global market. Thus, the process of material and technical, human and infrastructural base forming, which is receptive to innovative technologies, within VIOCs creates prerequisites for innovation activity and incentives for private innovation emergence. Statistical analysis shows that foreign innovative technologies borrowing mechanisms absolutely dominate in the oil industry. The most important technological processes in the industry, typically are acquired abroad, and small innovative enterprises within the technological clusters at VIOCs modify and adapt individual processes to the conditions of actual residence (Sinelnikov, 2008).

Thus, we can assume that the borrowing mechanisms are particularly important for vertically integrated oil companies, allowing them to catch-up technological delay with a significantly lower cost than the implementation of innovative "catch-up" policy and the need to spend financial, intellectual, informational, and personnel resources to reinvent everything. According to experts, the use of borrowing mechanisms of advanced technologies at least $35 \%$ cheaper than the development of advanced technologies with their own forces and resources (Azarov, 2012).

In terms of borrowing mechanism's using in the procurement of innovative technologies together with them in VIOCs the innovative management methods, quality control, training come, external relations are created through the transfer of knowledge, direction of employees in their local branches and cooperation with local research organizations take place. In other words, the use of borrowing mechanism in VIOCs entails a multiplier effect, when borrowing institutions begin to form in related industries, thereby contributing to mutual rapid innovative development.

\subsection{The Algorithm of Innovative Development Model Creation of a Vertically Integrated Oil Company Production Potential Is Suggested}

The foreign innovative technology borrowing is accompanied by the innovative management methods mandatory implementation, which include mandatory training and retraining of personnel associated with the management and the technology operation. Sources of innovative and management effectiveness growth of vertically integrated oil companies are (Bulatov, 2007):

- concentration of financial, intellectual, managerial, financial, and information resources for innovative growth and development, or the acquisition of the most advanced innovative technologies of oil production, its transportation, refining and marketing;

- staff motivation system creation at all levels to obtain the most effective final result at all stages of company innovation strategy implementation;

- tools availability for the creation and development of innovative infrastructure, development of small innovative enterprises clustered network performing specific innovative developments for the parent company;

- the possibility of organizing an effective information exchange between production and scientific- research units, which allow to reduce the time and expenses on technological innovations development; 
- reduction of transaction costs of innovation development by reducing administrative, financial and personnel barriers in innovative growth;

- reducing of all kinds of costs due to more rational use of space, facilities, information and material resources;

- company's relatively high level of stability during periods of demand fluctuating on oil and oil products, which ensures the maintenance of the necessary level in overall profitability;

- innovation risks minimization associated with changes in technology, equipment, faults and mistakes in personnel training, administrative errors, acts and omissions.

Values of indicators characterizing the innovative development level of the vertically integrated oil company production potential are calculated

The values of the indicators characterizing the innovative development level of the vertically integrated oil company production potential, relate to pre-defined evaluation criteria, and, according to them, values are assigned to points

Obtained points are summed, the coefficient of the components innovativeness development and production capacity of the vertically integrated oil company is determined in general

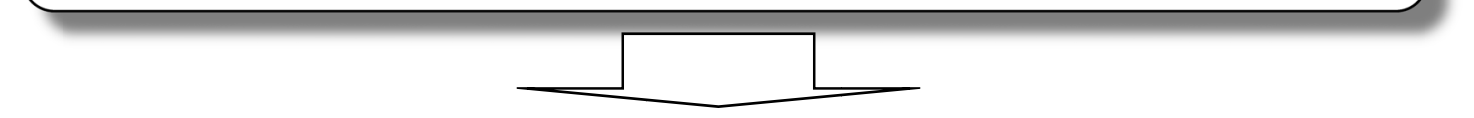

The components innovativeness coefficient dynamics in development and production of the vertically integrated oil companies capacity in general is analyzed, the strengths and weaknesses in its productive capacity development are identified

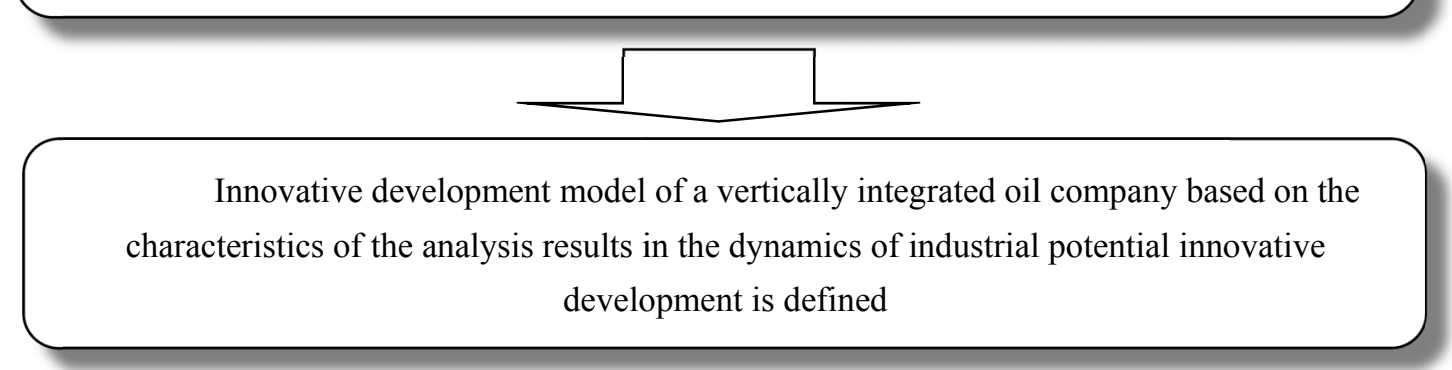

Figure 2. A fragment of the algorithm for model creation of a vertically integrated oil company productive capacity innovative development

All this together make a system of tools that ensure the most efficient development and implementation of innovative technological solutions in the framework of vertically integrated oil companies. Moreover, stabilization and active development of the petroleum sector of the national economy, increasing its efficiency make the preconditions for the development of innovative activity via the reform and further improvement of organizational and managerial structures of oil companies. On the other hand, to ensure the effective functioning of vertically integrated oil companies the major requirement is the establishment of management motivation and innovation performing system, the system creation of innovative receptivity of management at all levels. The 
concept of innovation receptivity is not limited to management, a huge role in this process belongs to the innovation infrastructure which must be created in VIOCs, thereby increasing their innovative capacity.

The study of organizational and managerial advantages of VIOCs allows assume that these benefits will prove crucial in the innovative models implementation of their productive capacities development. The basis of this model (Gilyazutdinova et al., 2009) can be effectively applied in the framework of vertically integrated oil companies.

Figure 2 presents a fragment of the algorithm for model creation of a vertically integrated oil company productive capacity innovative development. Implementation of the presented algorithm for model creation of a vertically integrated oil company productive capacity innovative development entails a range of innovative development models for a particular company, including:

- unidirectional innovative development model, when there is a development of one component of the innovative potential;

- polyindirectional innovative development model, when there is a development of two or more components of the innovative potential;

- sustainable innovative development model, when there is development of all components of the innovation potential;

- developing innovative development model, when the operation, and the development of productive capacities use the results of its innovative activity;

- stabilizing innovative development model, when the operation and the development of productive capacities involve the results of the innovative activity of third-party organizations;

- optimizing innovative development model, when the operation and the development of productive capacities the results of their own innovation activities and innovation performance of third-party organizations are used (Gilyazutdinova, Krasnova \& Ponikarova, 2011).

\section{Discussion}

To study the specificity and advantages of Russian vertically integrated oil companies and management the works of Alekperov (2009), Azarova (2012), Gochberg (2006), Bushuev (2008), Garaeev (2012), Kontorovich, Karzhubaev, Filimonova, Eder (2008), Kuznetsova (2011) and others are dedicated. The problem of the specificity of innovative activity in vertically integrated oil companies, as well as their advantages in the implementation of promising innovative projects are considered in works by Kovaleva (2000), Zaichenko (2010), Polterovich (2010), Gilyazutdinova, Bashkirtseva, Kiseleva Ponikarova (2009), Berezina, Cherepovitsin (2014), Bulatov (2007), Guseinov (2011), Sinelnicov (2008) and others.

\section{Conclusion}

Thus, the control system in the framework of vertically integrated companies helps to ensure an adequate level of management structure that integrates technological and managerial innovation options. Vertical integration allows ensure the preventive nature of managerial influence on production and technological processes due to previously given parameters of borrowed foreign innovative technologies, or own innovations within the structural research units. In addition, the control system of the vertically integrated oil companies may be strictly focused on specific innovative industrial risk because vertical integration and hierarchy of management structures allow concentrate all resources on specific goals achieving.

\section{Recommendations}

The obtained results allow structure the specificity of innovation in vertically integrated oil companies, to justify the expansion or contraction in each case of its own research base, to intensify the use of the mechanisms of borrowed foreign technologies, to establish joint innovative companies' complex developing innovative technologies in oil production. In addition, the results obtained can be useful for managers of vertically integrated oil companies, government authorities in the process of energy policy improving, the innovation processes enhancing in this area.

\section{References}

Alekperov, V. Y. (2009). Vertically integrated oil companies of Russia. Moscow. AUTOPAN.

Azarova, A. I. (2012) Innovative technologies in oil production and their reflection in the control system of the vertically integrated oil companies. Problems of accounting and Finance, 4(8), 35-47. 
Berezina, A. A., \& Cherepovicyn, A. E. (n. d.). Economic concept of oil and gas "smart field". Oil industry, 4, 14-15.

Bulatov, A. A. (2007). The problems of the oil sector transition on innovative way of development. Moscow University Bulletin, 6, 53-66.

Bushuev, V. (2008). Global oil and gas market: innovative trends. Moscow. MAKS Press.

Garayev, L. G. (2012). Comparative analysis of expenditures level on innovative activity of Russian and foreign oil and gas companies. Problems of Economics and management OGC, 11, 16-20.

Gilyazutdinova, I. V., Kiselev, S. V., Bashkirtseva, N. Y., \& Ponikarova, A. S. (2009). Industrial risks management of innovative activity in the modernization process of regional petrochemical complex production capacity. Kazan: Publishing house of KNRTU.

Gilyazutdinova, I. V., Krasnova, A. V., \& Ponikarova, A. S. (2011). Some evaluation aspects of management system effectiveness of the industrial complex innovative development (on the example of the petrochemical complex of the Republic of Tatarstan) Bulletin of the Kazan technological University, 23, 211-217.

Gochberg, L. (2006). Innovation processes: trends and issues. Economist, 2, 50-59.

Guseinov, B. M. (2011). Innovative development of Russian oil and gas companies. Finance and credit, 1, 51-55.

Kontorovich, A. E., Korzhubaev, A. G., Filimonova, I. V., \& Eder, L. V. (2008). The innovative development of large sectors of the Russian economy: the oil complex. Novosibirsk: PRESS.

Kovaleva, A. I. (2000). Strategic management of innovative activity in vertically integrated oil companies. Moscow: MAKS Press.

Kuznetsova, N. A. (2011). The advantages of vertically integrated oil companies, as a complex transformation of the management structure. Modern scientific research \& innovation, 5, 56-64.

Poletrovich, V. M. (2010). The strategy of modernization of the Russian economy SPb, Aletheia.

Sinelnikov, A. A. (2008). Bases of innovative strategies formation for oil and gas companies. Problems of Economics and management of oil and gas complex, 9, 16-19.

The presidential decree No. 1403 dated 17 November 1992 "On peculiarities of privatization and transformation of state enterprises, production and scientific production associations in the petroleum, oil refining and oil product supply industry into joint stock companies". (1995). Collected legislation of the Russian Federation, 19.

The presidential decree of 1 July 1992 "On the status of production and scientific production associations in the fuel and energy complex". (1995). Collected legislation of the Russian Federation, 19.

The presidential decree of 14 August 1992 "On transformation of state enterprises, associations and organizations of fuel-energy complex into joint stock companies". (1995). Collected legislation of the Russian Federation, 19.

Zaichenko, V. Y. (2010). Innovation economy in the sphere of subsoil use of Russia is a strategic task in the development. Problems of Economics and management of oil and gas complex, 3, 22-27.

\section{Copyrights}

Copyright for this article is retained by the author(s), with first publication rights granted to the journal.

This is an open-access article distributed under the terms and conditions of the Creative Commons Attribution license (http://creativecommons.org/licenses/by/3.0/). 